\title{
Teachers Identity in the Modern World, and the Factors which Shape them up Professionally and Psychologically
}

\author{
Muhammad Saboor Hussain \\ Islamabad Model College for Boys, H-9 Islamabad, Pakistan \\ M. Manshoor Hussain Abbasi \\ Department of Humanities, COMSATS Institute of Information Technology, Islamabad, Pakistan \\ Email: manshoor_hussain@comsats.edu.pk \\ Muhammad Afzal Awan \\ Islamabad Model College for Boys, H-9 Islamabad, Pakistan \\ Aisha Farid \\ Department of Graduate Studies, National University of Modern Languages (NUML), Islamabad, Pakistan
}

\begin{abstract}
This mini field-based study has explored the issue of teacher identity in the field of SLE. It highlights the significance of the issue and gives a comprehensive review of the body of literature available in this comparatively newer focus of study in the field. This study reports that second language teachers are primarily concerned about student achievement and institutional evaluation beside numerous other factors such as job satisfaction, socio-economic concerns, choices of teaching strategies and tools and native and nonnative speaking issues which directly and indirectly influence the second language teacher identity. This study also reports a few very personal teacher narratives and finally concludes that today's second language teaching scenario is pleasant; teachers are enthusiastic, motivated and focused on student achievement which they believe is the end of all their endeavours.
\end{abstract}

Index Terms - teacher identity, second language, indirectly influence

\section{INTRODUCTION}

Most of the professions today have a symbolic as well as thematic image. It is not difficult to know what connotations, images and expectations are associated with doctors, lawyers and, or media men; so is almost the case with teachers. We are particularly concerned here with the English language teachers who teach English as second language in today's widely diverse educational scenario. We want to focus on their self-image beside their various socio-economic and professional images which keep on shaping up as they progress in their teaching career. These images together, define teacher identity on which there is a general agreement of scholars that it is a socially constructed and on-going reality.

On one level, one can say, teaching is an isolated profession and less empowered in political sense. Apparently, teachers do their job in a vacuum; in the classroom where they work with their students and, sometimes, they are not even influenced by the management and their colleagues but in reality, there are many factors that affect the teachers of a second language to define themselves especially with respect to the context of their teaching. These factors include why they are in the profession, what influenced them to take up teaching as a career, how they negotiate their identity with their learners, how they perceive themselves as a social beings, to what an extent they are satisfied in their present job and so on.

We have tried to explore some aspects of teacher identity through a mini-quantitative survey, and through a qualitative analysis of some brief written narratives collected from international teachers currently engaged in teaching English as second language. It may not give a very comprehensive picture but certainly touches some vital aspects that determine teacher identity to a certain extent and broadens our understanding how teachers of English perceive their success or otherwise and how they strive to match themselves with the context they work in.

\section{LITERATURE REVIEW}

'One of the simple facts of life in the present time is that the English language skills of a good proportion of its citizenry are seen as vital if a country is to participate actively in the global economy and to have access to information and knowledge that provide the basis for both social and economic development central to this enterprise or English 
teaching and English language teachers.'(Anne Burns \& Richards, 2009). Teaching of English is now taking the shape of a huge corporate sector which facilitates the larger rather global industrial growth. As English language is being used as means of communication in the post-colonial states in particular and the rest of the world in general, learning and teaching of English is becoming integral part of almost every economy. An effective communication, it is said, 'is the life blood of an organization' (Herta \& Murphy, 2007). English language teachers all over the world are not heading any industry apparently but they are providing the 'life blood' to the corporate sector by providing the matching communication skill training to millions of employees, planners and decision makers in today's global economy.

In this diverse scenario of today's global economy, both the teachers and the learners are faced with the crisis of identity. Hundreds and thousands of teachers are busy in teaching English language to millions and millions of students. This teaching and learning community consists of different nationalities, ethnic groups, a huge variety of languages and extremely diverse cultural norms, values, motives and aspirations.

Diversity is at the heart of English language teaching and learning. Whether it is an EFL context or ESL scenario, both teachers and learners have to establish their identity. When a teacher comes into contact with his or her learners, the process of identity negotiation becomes imperative.

There are many factors which may shape up the identity. These factors include 'personal biography, gender, culture, working conditions, age, and the school and classroom culture. The concept of identity thus reflects how individuals see themselves and how they enact their roles within different settings.' (Anne Burns \& Richards- 2009). A teacher is a man of flesh and blood otherwise; it is the classroom where he identifies himself through negotiation with his students. "In a course room, teacher/ learners negotiate their identity through the unfolding social interaction of a particular situated community, in relation to its specific activities and relationships." (Singh and Richards, 2006). the significance of context in which this identity negotiation process happens: "Knowing the school, the possibilities of the classroom space, the students, their neighbourhoods, the resources, the curriculum and policy, the supervising teacher - these are all crucial elements that affect what teachers can do, and how they negotiate and construct identity moment to moment." (Miller, 2004). Therefore, identity construction is a complex, dynamic, evolutionary and multi-faceted process.

Teacher is faced with many challenges. In the SLE literature, academics express these challenges in various terms; one of the discourses is what they call 'vision' and 'voice'. 'Vision' is the curriculum intent or policy input given to the teacher to implement whereas 'voice' is the name given to the emerging realities in the classroom and/or from the teaching context. (Tudor 2001) contends that 'vision' is epic whereas 'voice' is emic. The former is easily observable, generalizable, linear and positivistic whereas the later is dynamic, unpredictable and highly context embedded; to use (Freeman, 1996). Therefore, a teacher determines his identity amid the centrifugal forces (Tudor, 2001) as 'student rationalities', 'methodological rationalities', 'socio cultural rationalities', 'institutional and corporate rationalities' and above all 'teacher's own rationalities'.

In this complex and 'messy' scenario of teaching and learning, a teacher has to establish his identity. "It isn't just what you say or even how you say it, it is who you are and what you are doing while you say it", (Gee, 1996). In my opinion every single word that a teacher utters, every single gesture and every single remark counts in determining his identity. All teachers have their own "ways of being" in the classroom yet most will attest to the power of their students to grant or refuse a hearing.' (Miller, 2009). It certainly means that teacher has to see himself or herself with the lens of his/her students. In today's corporate sector, teachers are evaluated, by and large, by their students. It is the student community that is considered the most important to comment on a teacher's performance for obvious corporate demands.

What then is the teacher identity exactly and how does it take shape? It is really hard to reach an agreement on definition of identity. It has been seen in the context of time and space. "Identity is how a person understands his or her relationships to the world, how the relationship is constructed across time and space and how that person understands possibilities for future" (Norton 2000). In this sense identity construction is rooted in the past and present and also strongly connected with the future. "Identity is a constant ongoing negotiation of how we relate to the world" (PennyCook, 2001). It means teacher is directly influenced by the social context in which he/she works and continuously engages in the process of negotiation.

As argued earlier, identity is a socially constructed reality. 'it is relational, constructed and altered by how I see others and how they see me in our shared experiences and negotiated interactions' (Johnson, 2003). Like a good performer, one has to see time again how one is performing one's task. One has to revisit one's role again and again to see where one is, and how one is going on. Similarly, teacher identity requires the same practice. "Identity is defined (here) in the terms of the influences on teachers, how individuals see themselves, and how they enact their profession in their setting" (Varghese, 2006). Teaching, like law and medicine, is a practicing profession; every new day, every new teaching context brings a new experience. As the context changes, teacher has to redefine his identity.

On a broader canvas, "Identity is instantiations of discourses, systems of power/ knowledge that regulate and ascribe social values to all forms of human activity" (Morgan, 2004). Therefore, identity issue involves teachers own personal being, her/his natural likes and dislikes on the one hand and many external aspects such as the organization s/he works for, the student population, the cultural norms and values they own, the teaching material and tools and so on.

In a nut shell, therefore, it is evident that teacher identity is relational, negotiated, constructed, enacted, transforming, and transitional. To avoid digression, it is but pertinent and unavoidable to mention at least one more factor that 
determines, and or seriously affects teacher's identity. This vital issue is growing struggle of non- native English speaking teachers (NNEST) for their legitimacy, acceptance and recognition as equally competent, reliable and professional beings. There are many myths associated with native teachers about their originality, competence and quality of teaching. Colonialism is over, but its implications are not. The popular websites of recruiters across the world (see www.tefl.com etc.), clearly show the preference for native speakers in the job market. There is a constant struggle on rise among the NNEST to survive in the market and establish their identity amid this competition. This study has also touched this vital aspect, to a considerable extent.

Though teacher identity is comparatively newer issue in teaching learning literature yet this discourse is attracting a great deal of attention. "Identity is being recognized as a certain kind of person; identity is connected not to internal states but to performances in society. It is also an important analytical tool for understanding schools and society" (Gee, 2000-2001). Finding it a significant area of research, we have tried to throw light on a few of its dimensions in this short study.

\section{MethodOLOGY}

This study was conducted in Ontario, Canada. The sample population participating in the study consisted of 20 English Language teachers, 3 male and 17 female (16 NNEST and 6 native English speakers or near native, being born and brought up in Canada). These participants were all international teachers pursuing their Graduate studies at a Canadian University. They spoke 10 different languages as their L1 including, Urdu, Persian, Mandarin (Chinese), Croatian, Russian, Tamil, Spanish, Polish, Cantonese, and Punjabi. A questionnaire was distributed carrying structured questions reflecting upon various aspects that determine or directly/indirectly affect teacher identity.

All the participants were also invited to write a brief personal narrative, consisting of 3-5 lines, telling about a particular moment of pride in their teaching career. An effort was made to avoid unnecessary digression and length. The quantitative part of the survey provided empirical data for seeing the factual scenario of teaching the participants were faced with while the brief personal narratives allowed this researcher to peep into the lives of practicing second language teachers.

\section{A. Quantitative Analysis}

Humans have no choice as to their origin, color of skin, height and the place of birth etc. but they have been endowed enough intelligence to make careful choices regarding their career and apparent future plans. We may say that poets are born, not produced but about teachers it is very hard to pass such a judgement. Teachers, when asked about their initial entry into teaching, give absolutely diverse reflections. In the first part of the structured survey, the participants were asked to reflect upon the circumstances, reasons and major influences that led them to become ESL/EFL teachers. About $35 \%$ of the teachers expressed that they were destined to be teachers. About 35\% reported that they made a careful choice to become ESL/EFL teachers. Socio-economic reasons pushed $10 \%$ of them to join teaching. About $15 \%$ were inspired by someone (by their teachers primarily) to become teachers. There were about $5 \%$ who had various personal reasons for their choice, for example, one of the participants explained: "I wanted to be a life-long learner not just from books but also from others." It, therefore, can be concluded that more than one third of them were teachers by choice; overall, if we include personal, inspirational and careful choices, we can say three fourth of them were in the career for good reasons. So, we should expect positive and productive output from them keeping the other variables of success in mind. The broader scenario of teaching does not, in any case, seem bleak.

About the timing when they finally decided to become a teacher emerged varied responses. For $40 \%$ of the participants, university was the place that made up their mind to become teachers while $15 \%$ decided it after they had left the university. About $25 \%$ could decide to join teaching in their first or second career elsewhere, while $20 \%$ had already decided to become teachers right away from their secondary school. Again, it means a huge majority of teachers is coming up with a very careful plan and we must presume they are enthusiastic to deliver.

In their response to what was the greatest influence that led them to teaching, $45 \%$ spoke of personal preferences, $25 \%$ recalled their teachers who influence their personalities, $15 \%$ were motivated by their parents and about $10 \%$ were attracted by the social image of a teacher. Again, it seems fairly rosy picture. Just 5\% of them had their personal expressions. One participant, for example, added: "My experiences with children e.g. as camp counsellor, gymnastic instructor were the greatest influences."

To conclude, almost none of the participants in the study had any painful compulsion to report. On their back, there were inspiration, motivation and good reasons to be in the profession.

Job satisfaction is the eventual factor that shapes up our personal, social and professional image. This variable can affect every single aspect of one's personal, social and professional life. The level of satisfaction of the teachers in the field was assessed on the following scale: (Fig.1.1)

Level of challenge, importance and satisfaction with respect to various factors:

Diversity in the classroom: 


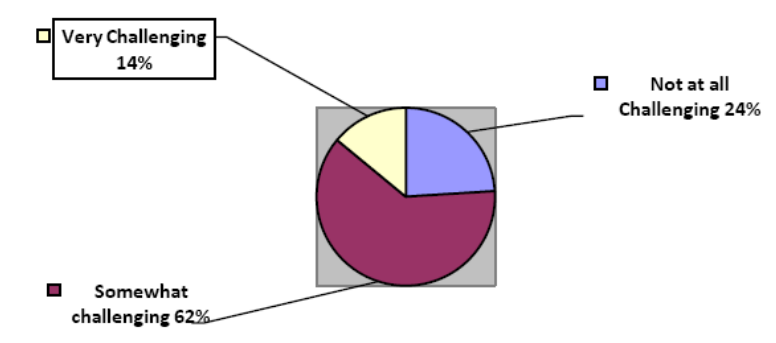

Figure 1.1.1

Skillful use of varied teaching strategies:

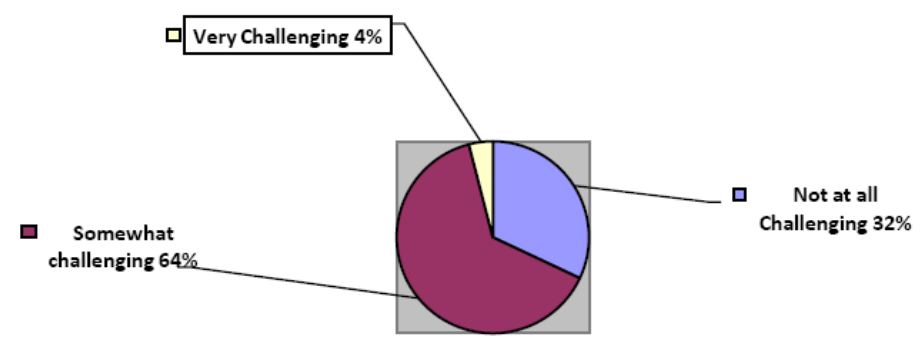

Figure 1.1.2

\section{Dealing with institutional pressure:}

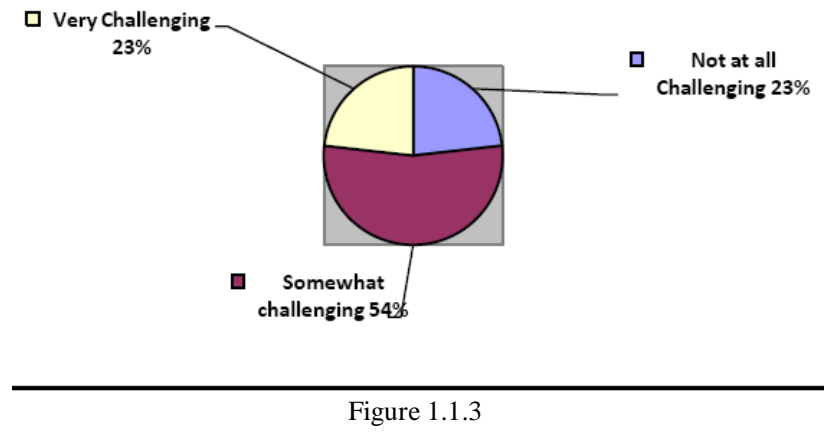

To what degree are the following important to you when you measure your own success as a teacher?

\section{Parents' feed back:}

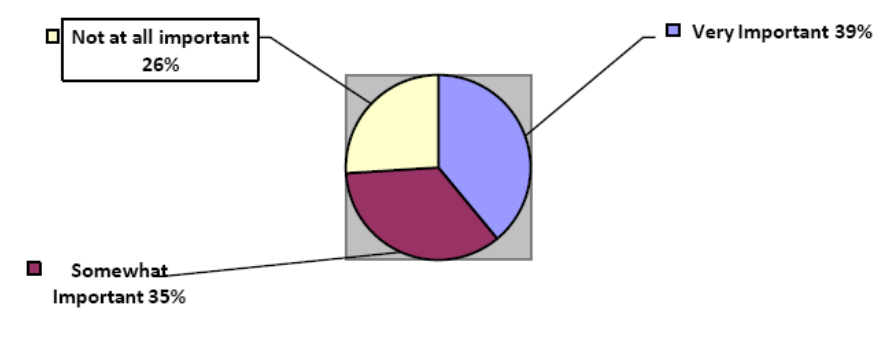

Figure 1.1.4

\section{Colleagues' appraisal:}




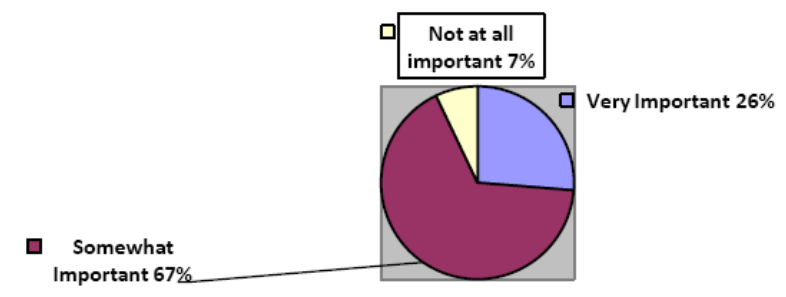

Figure 1.1.5

\section{Students' achievement:}

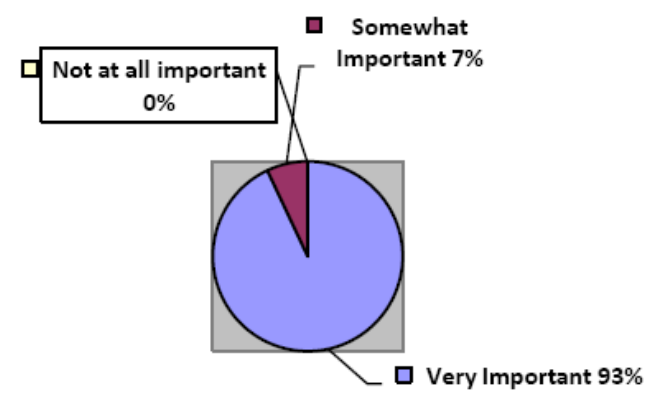

Figure 1.1.6

\section{Institutional Evaluation:}

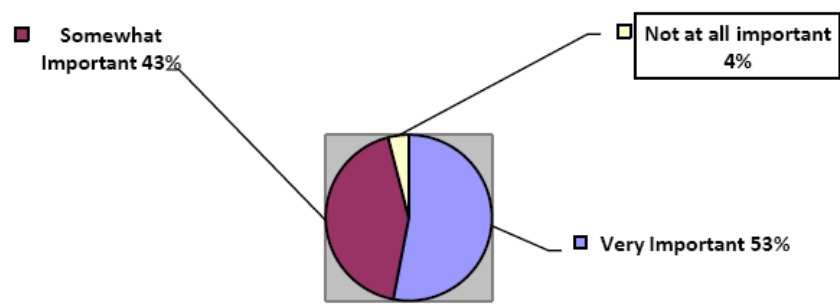

Figure 1.1.7

\section{Job Satisfaction}

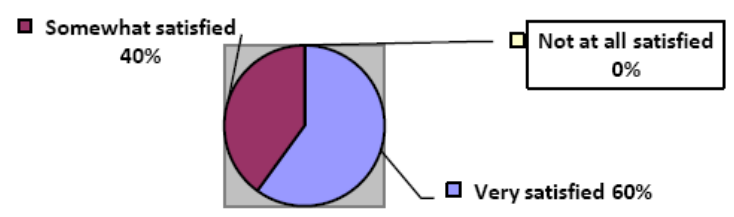

Figure 1.1.8

Giving the sagacity, intelligence and power of analysis of the readers, a due credit, we assume that it is not much difficult to assess how much weight-age the sample population of teachers is giving to various factors which help or their identity construction or make it problematic. We would like to refer to two core issues: student achievement and institutional evaluation. On the internal front, security within the classroom is the greatest concern of teachers. A 
language class is like a horse and teacher, a rider. The beauty of the horse lies in its ability to display its swiftness, charming gait and pride in performing its natural art, but if the rider does not strike a good balance in grant of liberty and control, his own survival is jeopardized. A horse never allows an ineligible rider to ride.

Thus apart from many rationalities, (Tudor, 2001) we have referred to in the previous pages, which influence teacher, the most predominant is the student's rationality and second most important one, of course, can be institutional evaluation. Both of them are pre-requisites, in a sense; no teacher can survive in the absence of either. It is perhaps, why no $(0 \%)$ teacher, in this study, could dare ignore the student achievement; all were $(100 \%)$ concerned about institutional evaluation at the same time, though with varying degrees.

What then is the role of a teacher? Fig 1.2 throws light on the role of teacher as is seen by teachers themselves in this mini-study.

\section{Role of a teacher (Fig.1.2)}

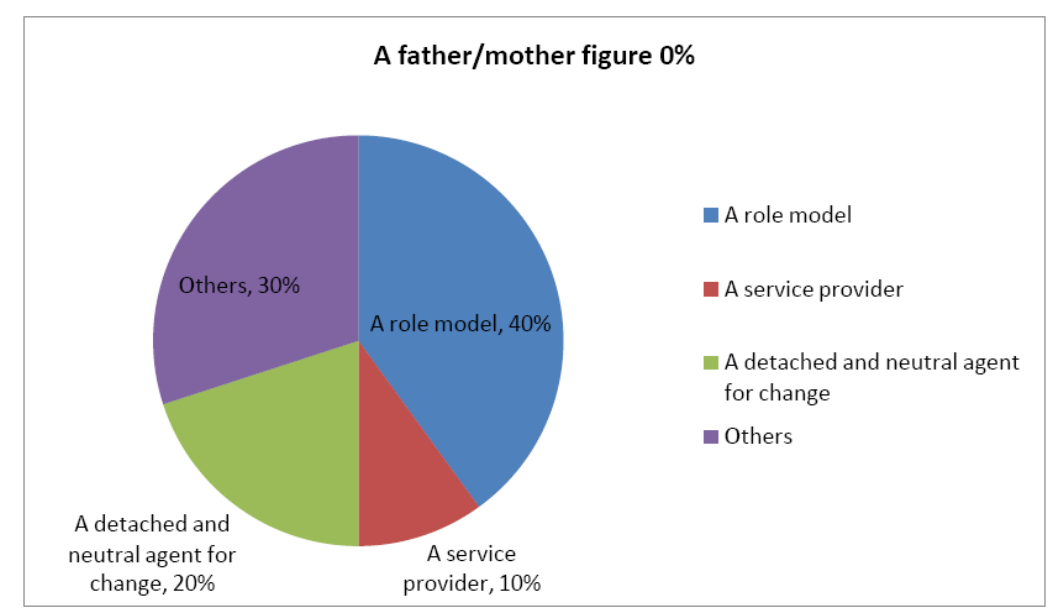

It is point to note that teachers of second language in today's teaching scenario are no more identifying themselves in the traditional motherly or fatherly role. A visible majority, however, identifies itself as role model for their students. The concept of teacher as service provider and neutral agent is also gaining weight. About one third (30\%) of teachers have their idiosyncratic versions of their roles as teachers such as: 'friend', 'facilitator', 'leader', 'motivator', 'mentor', 'educator', 'colleague' etc. one of the participants did not agree to any role proposed in this researcher, rather she liked to see the combination of all the above (Fig.1.2).

An effort was made to ascertain the nature of work environment in their home countries to understand the impact of socio-economic conditions on the teacher identity. Fig. 1.3 presents a glimpse of these conditions in the country of each participant.

Socio-economic realities and the image of teaching (Fig 1.3)

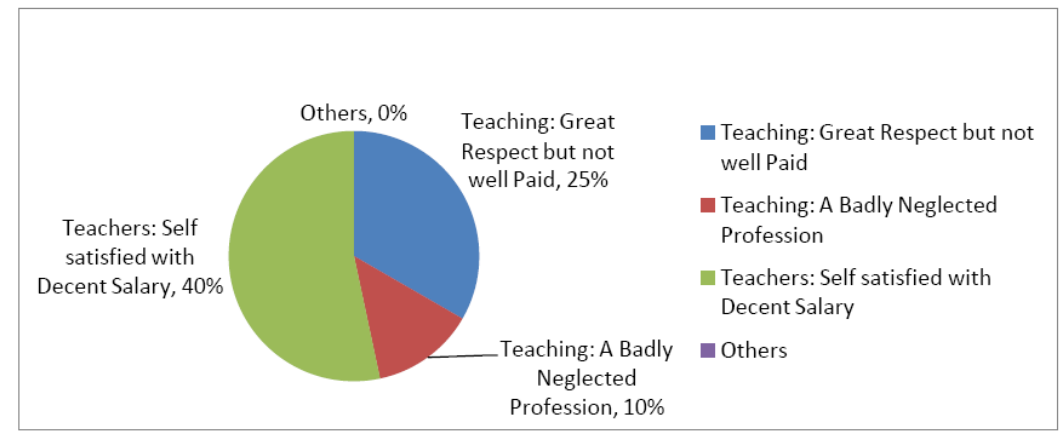

It is evident from this data that teaching is no more isolated; it is very much influenced by the socio-economic and other factors which are obviously different in every country.

The last, but not the least, is the growing realization among the ESL/EFL teachers about the Native and Non-native divide which, as pointed out earlier, has very strong root in the history of imperialism. There is a substantial body of literature available on this issue. To avoid digression, one can see the existing reality in the Fig. 1.4 below:

Feelings towards the native-non native divide: (Fig 1.4) 


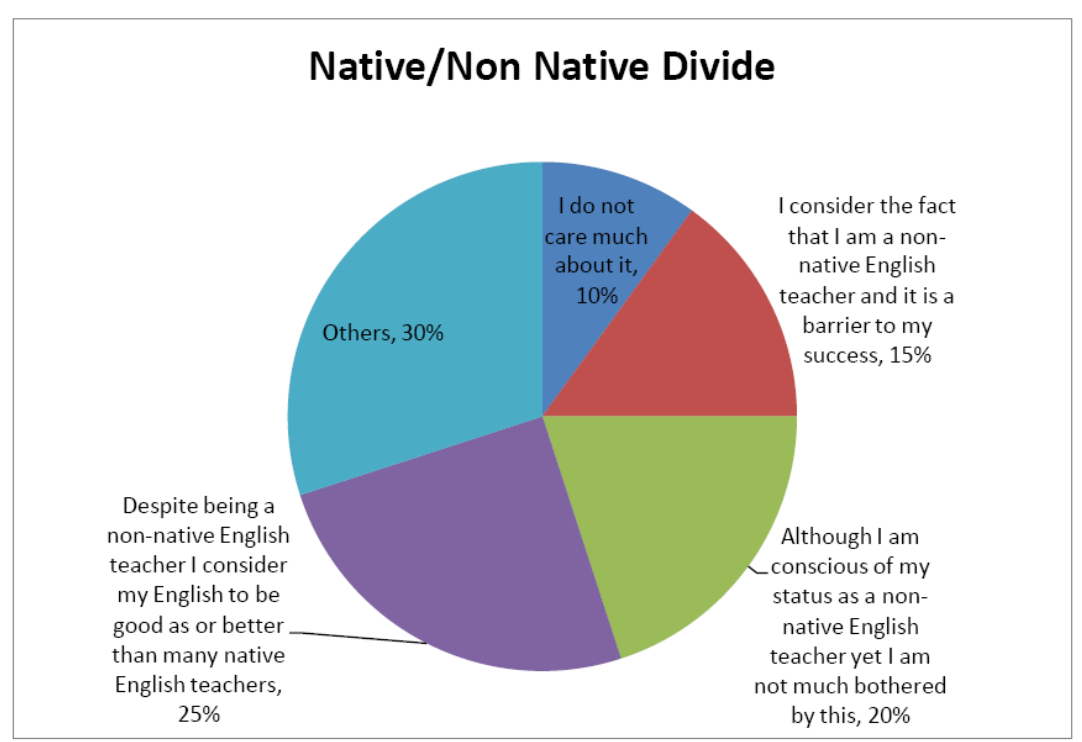

It is evident that this population of teachers has their concerns on the issue. A total of $30 \%$ teachers in this study were native speakers or born and brought up in the English speaking country and they also had white skin and blue or green eyes. It is heartening to note that about $80 \%$ are not totally bothered or much troubled about this divide but more than $20 \%$ of NNEST have clearly expressed their frustration on this divide.

\section{B. Qualitative Analysis}

Someone has rightly said: "people see us what we are but we see ourselves, what we are capable of doing." This study has shown that there is a visible assertion among the teachers about their roles of the ones who can bring positive change in the lives of their learners. Student achievement turned out to be the greatest moment of pride in the personal narratives this mini-research stove to elicit. About three fourth of the teachers ascribed their moment of pride to student achievement. About one fifth shared their pride about the award they were given or privilege they were offered, of course, in that case, the student achievement was the basic reason behind.

We would like to mention a few narratives to highlight how teachers identify themselves with respect to their learners' achievement.

A participant in the study expressed: “......I was delighted when one student in fact expressed that he wanted to be an English teacher in future because of my teaching........"

Tania, a comparatively less experienced teacher reported: "While teaching in Peru, we had evaluation forms which the students used to fill out and I got to read them at the end of the term. My students comments were very personal and detailed and at the same time very encouraging. It really helped me to see my efforts were being noticed and paid off. It was my best reward"

Another EFL teacher, Dan, from a thickly populated country gave vent to her feelings: "The greatest moment of pride in my career as EFL teacher was when I taught a class of about 160 college students. To make sure that everybody could hear me I took a recorder and a microphone every time. Beside careful preparation of teaching material, I corrected their compositions every other week to provide feedback for them. At the end of the class in the semester, students gave me a big warm applause. I took it as the reward for my sincere efforts."

As pointed out earlier, the process of negotiation starts forthwith a teacher comes into contact with his or her learner in a particular context.

Nina expressed her experience: "I taught in a private school. There was a group of teen age girls who belonged to high strata of society; they were very picky about instructors. I was sent to the class as replacement of a teacher who was knocked out by those girls. It was a test case from either side. The group was very critical at first, but in the second half of the class, they opened up and asked me to be their future teacher."

A similar narrative came up from another teacher, Ann, who handled a challenging class that only relieved her but also added to her confidence and even gave her a sense of pride: "There are abundant moments that brought pride and some unspeakable feelings. I will quote here a recent experience where I came across a class that was considered resistant to learning process. The previous teacher had tried every mode to bring forward their performance. In fact, it was later on I learnt that the material she had provided had the excellent and most beneficial content. I also sensed an attitude in the girls that kept them away from grasping the real essence of the subject. Nevertheless, and to my advantage, the number of students in that class was twenty-three and this gave me an encouragement to attend each girl individually and bring out her best performance while fighting against respective weaknesses. In their second terminals with me their performance showed a marked change. We became hopeful. It was their individual comments, that till now I receive from them, where they say, 'Madam, we started understanding language because of you...' Their 
feedback and their performance at exams and their comments both become truly encouraging for me to work and prove my humble mettle..."

The overall scenario through these perspectives reflects that teachers are more focussed on delivering the best of what they can to gear up students to learning. Student achievement is at the heart of what the teaching is all about. '... it is the learner who must remain at the centre of the process, for no matter how much energy and effort we expend, it is the learner who has to do the learning.' (Nunan, 1995). The student achievement and the institutional evaluation or pressures are the two greatest concerns of teachers in today's ESL/EFL scenario; of the two, student achievement is far more important than the other.

\section{CONCLUSION}

It is rightly said that self knowledge is the best knowledge. It is high time English Language Teachers in particular and all other teachers in general assess, evaluate and value themselves and improve their self image to survive in a dignified way in the present day world. Such continuous self studies will give them their due status in the society on one hand and on the other hand polish, grow and develop their professional skills. A teacher should know something about everything and everything about something. So his/hers is a never ending voyage into the ocean of knowledge. The best and most vital part of this voyage should be self exploration and self knowledge thereby putting his/her identity in the right perspective.

Putting aside our personal perception what invaluable services English teachers render, this study has shown that English teacher are struggling for bringing changes in lives of their students. Empowering students, it appears, is at the top of their agenda. English language learning is an instrument of empowerment in many post-colonial states beside the flourishing states such as China, Russian states and countless other counties. “... language teachers are not simply teaching language as neutral vehicle for expression of meanings and ideas, but should be engaged both in reflecting upon ideological forces that are present in their classrooms, schools and communities and in empowering their learners with the language knowledge and skills they need to be able to function as moral agents in society" (Richards, 2009). Who can do better service than English teachers who bring change in the lives of refugees and immigrants, aspirants of knowledge who have greater designs to study in the centres of Imperialism? A society that produces better speakers is never at the risk of dictatorship, autocracy and inequality. Language teachers give the students the tongue to speak; hence, they do a far greater job than teaching language which, in its narrowest sense, is an instrument of communication.

\section{REFERENCES}

[1] Anne Burns and Richards, (2009). The Cambridge Guide to Second Language Teacher Education, UK, Cambridge university press.

[2] Freeman, D. (1996). The "unstudied problem": research on teacher learning in language teaching. in D. Freeman J. Richards (eds.), teacher learning in language teaching (pp.351-78). Cambridge: Cambridge University Press.

[3] Gee,. (2000-2001). Identity as the analytic lens for research in education. in W. Secada (ed.), Review of Research in Education 25 (pp.99-126). Washington D.C. : American Educational Research Association.

[4] Gee. (1996). Social linguistics and illiteracies: ideologies in discourses (2nd ed.) London: Taylor \& Francis.

[5] Herta and Murphy, (2007). Effective Business Communication, India, Tata McGraw-Hill Publishing Company.

[6] Johnson, K., (2003). "Every experience is a moving force": identity growth through mentoring. Teaching and teacher education, 19, 787-800

[7] Margon. (2004). Teacher identity as pedagogy towards a field - internal conceptualization in bilingual and second language education. Bilingual education and bilingualism, 7 (2\&3), 172-188.

[8] Miller, (2004). Social languages and schooling: the uptake of sociocultural perspectives in school', in Margaret Hawkins (ed.), language learning and teacher education (Clevedon: multilingual matters):113-46.

[9] Norton, (2000). Identity and language learning: gender, ethnicity and educational change. London: Longman.

[10] Nunan, (1995). 'Closing the gap between learning and instruction', TESOL quarterly 29:133-58..

[11] Pennycook, A. (2001). Applied Linguistics with an Attitude, Ch 7, New Jersey: Lawrence Erlbaum associates.

[12] Pennycook, A. (2004), Initials. Critical applied linguistics: a critical introduction. New Jersey: Lawrence Erlbaum associates.

[13] Singh and Richards. (2006). Teaching and learning in the language teacher course room: a critical socio-cultural perspective, RELC Journal 37(2):149-75.

[14] Tudor, I. (2001). The Dynamics of Language Classroom, UK, Cambridge University Press.

[15] Varghese. (2006). Bilingual teachers- in - the - making in Urban town. Journal of multilingual and multicultural development, 27(3) 211-224.

Muhammad Saboor Hussain S/O Abdul Majeed is basically from a village called Narala Kalan (now I-8 Sector of Islamabad) which existed before President Ayub Khan' era. He got his early education from Rawalpindi, Masters in English from National Institute of Modern Languages, Islamabad, affiliated with Quid-i-Azam University, Islamabad (now National University of Modern Languages, Islamabad). His date of birth is 24th of May 1975. He is the youngest Assistant Professors in Federal Government Education Department as he got the Assistant Professorship at the age of 30 years and one month. Right after doing Masters in 1998, he started teaching at his mother institute, NIML as a Part Time Teacher. Soon he was selected at Army Burn Hall College as Lecturer in English on regular basis. After a few months of teaching there, he got into Punjab Government Education Department as 
a Lecturer in English through PPSC on 26th of May 1999 (started service at Govt. Sir Syed College, Katas, Chakwal and then got transferred to Govt. Gordon College, Rawalpindi). After serving there for about three years, he got selected as a lecturer in English at NUML and served in FC (Functional Courses) Department of NUML for about three years. It was in June 2005 that he was selected as Assistant Professor of English (BS-18) and at present is posted at Federal Government College for Men, H-9, Islamabad. He has attended as well as conducted many workshops on various areas of English language teaching. He is near completion of his $\mathrm{PhD}$ Linguistics from National University of Modern Languages, Islamabad, coursework complete with 76\% marks and thesis, entitled, "Role of Affective Filter in teaching English to Adults in Pakistan" submitted under the sagacious supervision of Dr. Riaz Hassan.

M. Manshoor Hussain Abbasi joined CIIT in May 2006 as an Officer Grade (OG)-I. Currently; he has more than 8 years experience along with two Masters Degrees i.e. Masters in Mass Communication and Masters in English (Linguistics \& Literature). $\mathrm{He}$ also has 05 research proceedings, one International publication and two more are accepted in International Journals. He has been involved in various activities i.e. teaching Courses, organizing Convocations and Conferences and many other administrative duties at CIIT. He also completed his MS in Management with CGPA 3.29 from Center for Advanced Studies (CASE), Islamabad (Affiliated with UET, Taxila). Manshoor has been involved in teaching since last five years in Humanities at CIIT with excellent feedback. His areas of interest are Business Communication and Communication Skills.

Muhammad Afzal Awan has been teaching at FG College for Men, H-9 as Lecturer in English/ Assistant Professor English since 19th January 1993. He has been teaching English as Second Language at Adult level with professional commitment and consequently producing admirable results. He is an asset to this profession due to some golden qualities of head and heart needed for the teaching profession. He is deeply involved with the students given under his charge. He uses innovative teaching techniques, methods and approaches such as Direct Method, Student Centered Approach, Interactive Approach, Communicative Approach and Eclectic Approach, to name a few. As a person he is a very likeable personality. His is a social, polite and challenge accepting personality. He likes team work and does wonderfully well both as a team leader and team member. His communication abilities are excellent and abilities to do concentrated tasks great. At present, he is in Canada, migrated with his family and studying at a University doing his Masters.

Aisha Farid is married and has a 5 years old son. She lives in Islamabad. She is MA English and B.Ed. At Present she is working as an Assistant Professor in the Faculty of English language, Literature and Applied Linguistics at National University of Modern Languages, Islamabad. She is also doing her PhD in Linguistics. The topic of her research is A Comprehensive Analysis of English Language Learning assessment in Higher Education in Pakistan. She has obtained first division throughout in her educational career. She did her Intermediate from her native city Jhang, B.A from Islamabad, MA from National Institute of Modern Languages, Islamabad and B.Ed from Allama Iqbal Open University, Islamabad. In addition to this, she has also done Diploma in English form NIML. She has adopted teaching as a profession since teaching has been her ambition. She started teaching right after the completion of her MA, in the same institute from where she did her MA. After a year, she got selected as a regular Lecturer in Punjab government where she served for three years. Then she joined NUML as a Lecturer, where, after two years, she was selected as Assistant Professor. Apart from her regular job, she has been engaged in different workshops as a resource person for variou s areas of English Language Teaching like Technical Writing Skills, Business Communication, Reading Comprehension and Composition Skills, Teaching English and Assessment at various places like COMSATS and Allama Iqbal Open University. Apart from teaching, she has always been enthusiastically participating in other activities as well. While serving in Punjab government, she was member of different committees running certain administrative works like examination committee, admission committee etc. Moreover, she has been the Coordinator for the evening courses for two semesters at NUML. She has also served as the Coordinator at NUML for various short courses. She has also been a member of examination committee at NUML. She has also served as a Judge for English speech/debate contests at various places. 